\title{
Taxonomic Repositioning of Xanthomonas campestris pv. viticola (Nayudu 1972) Dye 1978 as Xanthomonas citri pv. viticola (Nayudu 1972) Dye 1978 comb. nov. and Emendation of the Description of Xanthomonas citri pv. anacardii to Include Pigmented Isolates Pathogenic to Cashew Plant
}

\author{
Marco Aurélio Siqueira da Gama, ${ }^{\dagger}$ Rosa de Lima Ramos Mariano, Wilson José da Silva Júnior, Antônio Roberto Gomes de \\ Farias, Maria Angélica Guimarães Barbosa, Marisa Álvares da Silva Velloso Ferreira, César Raimundo Lima Costa Júnior, \\ Liliana Andréa Santos, and Elineide Barbosa de Souza
}

First, second, third, fourth, and eighth authors: Área de Fitossanidade, Departamento de Agronomia, Universidade Federal Rural de Pernambuco, Av. Dom Manoel de Medeiros, s/n, Dois Irmãos, CEP 52171-900, Recife-PE, Brazil; fifth author: Empresa Brasileira de Pesquisa Agropecuária, Semiárido; BR 428, Km 152, Zona Rural, CEP 56302-970 Petrolina-PE, Brazil; sixth author: Departamento de Fitopatologia, Instituto de Ciências Biológicas, Universidade de Brasília, Campus Universitário, Asa Norte, CEP 70910-900, Brasília-DF, Brazil; seventh author: Departamento de Genética, Universidade Federal de Pernambuco, Av. Professor Moraes Rego, 1235, Cidade Universitária, CEP 50670901, Recife-PE, Brazil; and ninth author: Área de Microbiologia, Departamento de Biologia, Universidade Federal Rural de Pernambuco, Av. Dom Manoel de Medeiros, s/n, Dois Irmãos, CEP 52171-900, Recife-PE, Brazil.

Accepted for publication 17 April 2018.

\begin{abstract}
Grapevine bacterial canker, which is caused by Xanthomonas campestris pv. viticola, is one of the most important grapevine diseases in the northeastern region of Brazil. This disease causes severe damage and represents a high potential risk to the development of Brazilian viticulture. In turn, pigmented isolates pathogenic to cashew plant, making cashew fruit unfit for sale, also have been detected in Northeastern Brazil. Given that the taxonomic position of these bacteria is unclear, the multilocus sequence analysis (MLSA) technique, average nucleotide identity (ANI) values and tetranucleotide frequency correlation coefficients (TETRA) were used to analyze their phylogenetic

relationship in relation to other Xanthomonas species. X. campestris pv. viticola was closely related to $X$. citri pv. mangiferaeindicae (repetitive-polymerase chain reaction [rep-PCR], MLSA, and ANI) and $X$. citri subsp. citri (MLSA and ANI). Pigmented isolates pathogenic to cashew plant were closely related to $X$. citri pv. anacardii (rep-PCR, MLSA, ANI, and TETRA). The results obtained in this study support the emendation of the description of X. citri pv. anacardii to include pigmented isolates of Xanthomonas pathogenic to cashew plant. In addition, the reclassification of $X$. campestris pv. viticola as $X$. citri pv. viticola comb. nov. is suggested.
\end{abstract}

Brazil is the eighth largest fruit producer worldwide (Food and Agriculture Organization of the United Nations 2018), and the northeastern region is the main tropical fruit producer and exporter (Lopes et al. 2009), accounting for more than $99 \%$ of the national grape (Vitis vinifera L.) export (Lazzarotto and Fioravanço 2013) and more than $98 \%$ of cashew (Anacardium occidentale L.) production (Instituto Brasileiro de Geografia e Estatística 2018). In this region, bacterial canker caused by Xanthomonas campestris pv. viticola (Nayudu) Dye is one of the most important grapevine diseases, responsible for severe damage and representing a serious potential risk to Brazilian viticulture development (Araujo et al. 2005; Rodrigues Neto et al. 2011). This bacterium cause cankers on the twigs, branches, petioles and veins as well as depressed dark lesions on berries. In turn, pigmented isolates of X. citri (ex Hasse) Gabriel et al. pathogenic to Anacardiaceae, which apparently are

${ }^{\dagger}$ Corresponding author: M. A. S. Gama; E-mail: mas.gama@yahoo.com.br

Funding: We thank the Foundation of Support for Science and Technology of the State of Pernambuco (Fundação de Amparo à Ciência e Tecnologia do Estado de Pernambuco [FACEPE]) for the Doctoral scholarship awarded to M. A. S. Gama and the Brazilian National Council for Scientific and Technological Development (Conselho Nacional de Desenvolvimento Científico e Tecnológico [CNPq]) for research scholarships awarded to the researchers E. B. Souza and R. L. R. Mariano and financial support (Proc. No. 477521/2011-8).

*The $\boldsymbol{e}$-Xtra logo stands for "electronic extra" and indicates that one supplementary figure and four supplementary tables are published online.

(c) 2018 The American Phytopathological Society variants of $X$. citri pv. anacardii (Starr and Garces) Constantin et al. were recently detected in the Brazilian northeast, causing angular leaf spots and dark lesions in the leaf veins and surrounding tissues as well as dark necrotic lesions on fruits of cashew tree (Gama et al. 2011; Viana et al. 2006). Considering that young infected fruit results in nuts unfit for sale (Viana et al. 2006), these isolates represent a serious threat to this crop within the region.

The causal agent of grapevine bacterial canker was initially named Pseudomonas viticola Nayudu (Nayudu 1972) and subsequently reclassified as X. campestris pv. viticola (Young et al. 1978), which currently remains the valid nomenclature (Bull et al. 2010). However, since $1995, X$. campestris has been known to only harbor isolates pathogenic to brassicas (Vauterin et al. 1995). Since that time, studies performed based on the $r p f$ (regulator of pathogenicity) region (Takita et al. 2004), the copA gene (Marques 2007), the gyrB housekeeping gene (Parkinson et al. 2009), comparative analyses of genomic sequences (Takita et al. 2006), and genomic analysis (Bansal et al. 2017; Midha and Patil 2014) have demonstrated a close relationship between $X$. campestris pv. viticola and $X$. citri pv. citri (ex. Hasse) Constantin et al. (synonymy $X$. citri subsp. citri). Contradicting these results, multilocus sequence analyses (MLSA) $(r p o A, r p o B$, and spacer region $16 \mathrm{~S}-23 \mathrm{~S}$ rDNA) and DNA-DNA hybridization have demonstrated that $X$. campestris pv. viticola is more closely related to X. axonopodis sensu Rademaker et al. (2005) (Ferreira-Tonin 2012; Ferreira-Tonin et al. 2011).

Over the years, the taxonomic positions of the pathovars of $X$. citri pathogenic to Anacardiaceae have been modified numerous times. Originally, these pathovars were named Bacillus mangiferae 
(Doidge 1915) and were reclassified as Pseudomonas mangiferaeindicae (Patel et al. 1948a, b) and Erwinia mangiferae (Breed et al. 1957) until being correctly placed in genus Xanthomonas, initially as X. campestris pv. mangiferaeindicae (Robbs et al. 1974). Next, a new reclassification was performed based on the pathological variation and evolutionary divergence of the genomes observed using amplified fragment length polymorphisms (AFLP), in which $X$. campestris pv. mangiferaeindicae was proposed to be separated into three pathovars, which resulted in the following current taxonomic position: X. axonopodis pv. mangiferaeindicae (Starr and Garces) AhYou et al. (angular leaf spot of mango), $X$. axonopodis pv. anacardii (angular leaf spot of cashew), and X. axonopodis pv. spondiae (Starr and Garces) Ah-You et al. (angular leaf spot of ambarella) (Ah-You et al. 2007). Based on data from MLSA, DNA-DNA hybridization, average nucleotide identity (ANI) values and Biolog GEN III MicroPlate System, a new reclassification for pvs. mangiferaeindicae and anacardii was proposed: $X$. citri pv. anacardii and $X$. citri pv. mangiferaeindicae (Constantin et al. 2016). Interestingly, both pigmented and nonpigmented isolates of Xanthomonas have been isolated from cashew trees in Brazil (Gama et al. 2011), however pigmented strains have not been included in the reclassification studies conducted to date (Ah-You et al. 2007, 2009; Constantin et al. 2016).

Because $X$. campestris pv. viticola is considered a quarantine pest present in Brazil restricted to the states of Bahia, Ceará, Pernambuco, and Roraima (Regulatory Instruction 59/2013) (Brazil Ministério da Agricultura, Pecuária e Abastecimento 2001) and pathovars of $X$. citri pose higher risk in farming plants of family Anacardiaceae in northeastern Brazil (Gama et al. 2011), the objective of this study was to clarify the taxonomic position of these plant pathogenic bacteria. Thus, we used MLSA, ANI values, tetranucleotide frequency correlation coefficients (TETRA) and Biolog GEN III MicroPlate System to reclassify $X$. campestris pv. viticola as $X$. citri pv. viticola (Nayudu 1972) Dye 1978 comb. nov. and perform the emendation of the description of $X$. citri pv. anacardii to include pigmented strains pathogenic to cashew plant.

\section{MATERIALS AND METHODS}

Bacterial isolates, culture conditions, and DNA extraction. Eighteen isolates of $X$. campestris pv. viticola and 10 pigmented isolates pathogenic to cashew plant were selected to determine their taxonomic position (Table 1 ). The $X$. campestris pv. viticola isolates were selected from a collection of 116 isolates (Supplementary Table $\mathrm{S} 1$ ) based on rep-PCR analysis performed in this study and the pigmented isolates pathogenic to cashew plant were selected based on intrapathovar variability described in previous studies (Gama et al. 2011). Four isolates of $X$. campestris pv. passiflorae, four isolates of $X$. citri pv. anacardii and one isolate each of $X$. citri pv. mangiferaeindicae, $X$. campestris pv. campestris, $X$. citri subsp. malvacearum, $X$. vesicatoria, and Pseudomonas syringae pv. tomato were included in the metabolic and molecular analyses for comparison.

To determine the taxonomic position of $X$. campestris pv. viticola and the pigmented isolates pathogenic to cashew plant, the $g y r B$ (PopSet: 188090225), rpoD (PopSet: 188090463), fyuA (PopSet: 188090027) and dnaK (PopSet: 188089823) gene sequences from 46 isolates representing 23 species of genus Xanthomonas and subgroups 9.1 through 9.6 of $X$. axonopodis sensu Rademaker et al. (2005) were selected from the GenBank database and included in the phylogenetic analyses.

Unless otherwise noted, the isolates were cultured in NYDA medium ( $20 \mathrm{~g}$ of agar, $10 \mathrm{~g}$ of dextrose, $5 \mathrm{~g}$ of peptone, $5 \mathrm{~g}$ of yeast extract, and $3 \mathrm{~g}$ of meat extract, completing the volume with sterile distilled water $[\mathrm{SDW}$ ] to $1,000 \mathrm{ml})$ for $36 \mathrm{~h}$ at $29^{\circ} \mathrm{C}\left( \pm 0.5^{\circ} \mathrm{C}\right)$.

Molecular characterization. DNA extraction from the isolates used in this study was performed using the MiniPrep kit for bacterial genomic DNA extraction (Axygen Biosciences, MA) following the manufacturer's recommendations. The genomic DNA was quantified as previously described (Gama et al. 2011).
The repetitive element palindromic (REP), enterobacterial repetitive intergenic consensus (ERIC), and BOX element (BOX)-polymerase chain reaction (PCR) analyses were performed according to Louws et al. (1994), with some modifications: $1 \times$ PCR Master Mix $2 \times(0.05$ $\mathrm{U} / \mu \mathrm{l}$ of Taq DNA polymerase, reaction buffer, $4 \mathrm{mM} \mathrm{MgCl}, 0.4 \mathrm{mM}$ of each dNTP), $2 \mu \mathrm{M}$ of each primer, and $200 \mathrm{ng}$ of DNA. The samples were amplified in a thermocycler, model PTC-100 (MJ Research, MA). Negative controls (DNA-free reactions) were included in all of the experiments to test for the presence of contaminants. Twelve microliters of each amplification reaction was mixed with $3 \mu \mathrm{l}$ of loading buffer and $2.5 \mu \mathrm{l}$ of Safe SYBER, applying a total volume of $17.5 \mu \mathrm{l}$ in each well of the gel. The amplified fragments were visualized using a $1.5 \%$ agarose gel. The electrophoretic run was performed for $3 \mathrm{~h}$ at $80 \mathrm{~V}$ in $0.5 \times$ Trisborate-ethylenediaminetetraacetic acid (EDTA) (TBE) buffer using the GenRuler 100-bp DNA Ladder (Fermentas Life Sciences, Ontario, Canada) and GenRuler 1-kb DNA Ladder (Fermentas Life Sciences) markers. Next, the gel was photographed. The analyses were performed two times.

The amplification profiles generated with the REP-, ERIC-, and BOX-PCR primers were visually analyzed according to the presence (1) or absence (0) of 100- to 3,000-bp bands, and only reproducible bands (present in both analyses) were recorded. The data generated with each primer were analyzed separately and together using the FreeTree program (Pavlicek et al. 1999). The profiles of the strains of $X$. campestris pv. viticola and the species/pathovars of Xanthomonas described on Table 1 were analyzed separately. The Jaccard similarity coefficient was used to determine the genetic relationships between the isolates, and a distance tree was constructed using the unweighted pair group method with arithmetic mean (UPGMA) method. Bootstrap analyses with 1,000 replicates were conducted to evaluate the internal consistency of the branches (Hampl et al. 2001).

Phylogenetic characterization. Amplification and sequencing. Primers were used that have been developed to amplify partial sequences of the genes gyrB housekeeping (DNA gyrase beta subunit), rpoD (RNA polymerase sigma subunit), fyuA (tonBdependent receptor), dnaK (chaperone protein dnaK) (Young et al. 2008 ), and $h r p B$ for the pathogenicity and hypersensitive response cluster (Leite et al. 1994). The reactions comprised the following: $1 \times$ PCR Master Mix, $0.5 \mu \mathrm{M}$ of each primer, and $200 \mathrm{ng}$ of DNA. The samples were amplified in a thermocycler, model PTC-100, and subjected to the following conditions: $g y r B$ and $r p o D-94^{\circ} \mathrm{C}$ for $3 \mathrm{~min}$, followed by 30 cycles of $30 \mathrm{~s}$ at $94^{\circ} \mathrm{C}$ for denaturation, $30 \mathrm{~s}$ at $54^{\circ} \mathrm{C}$ for annealing of the primers, and $1 \mathrm{~min}$ at $72^{\circ} \mathrm{C}$ for extension of the new strand; $h r p B-95^{\circ} \mathrm{C}$ for $3 \mathrm{~min}$, followed by 30 cycles of $30 \mathrm{~s}$ at $95^{\circ} \mathrm{C}$ for denaturation, $30 \mathrm{~s}$ at $52^{\circ} \mathrm{C}$ for annealing of the primers, and $1 \mathrm{~min}$ at $72^{\circ} \mathrm{C}$ for extension of the new strand. A 10 -min cycle at $72^{\circ} \mathrm{C}$ was performed for the final extension of the sequences of the three genes. Negative controls (DNA-free reactions) were included in all of the experiments to test for the presence of contaminants. The amplified fragments were visualized by $1 \%$ agarose gel and an electrophoretic run performed for $1.5 \mathrm{~h}$ at $80 \mathrm{~V}$ in $0.5 \times$ TBE buffer using the GenRuler 100-bp DNA Ladder marker. The PCR products were purified using a Clean-up kit (Axygen Biosciences), and the forward and reverse strands for each marker were sequenced by Macrogen (Seoul, South Korea). Quality analysis of the nucleotide sequences and contig assembly were performed using the Staden Package (Staden et al. 1998).

Phylogenetic analyses. The nucleotide sequences were aligned using Muscle (Edgar 2004), available in Molecular Evolutionary Genetic Analysis (MEGA) v. 5.20 (Tamura et al. 2011), and manually adjusted to allow for maximum similarity of the sequences. The ends of the sequences were trimmed, resulting in 865-, 873-, 698-, 940-, and 731-nucleotide sequences for gyrB, rpoD, fyuA, dnaK, and $h r p B$, respectively.

Two approaches were performed for MLSA. In the first approach, analyses were performed with the sequences (Supplementary Table S2) of the Xanthomonas isolates used in this study (Table 1) together with sequences of 23 species of Xanthomonas collected from the GenBank 
database using the partial sequences of the $g y r B$, rpoD, fyuA, and $d n a K$ genes alone as well as the concatenated sequence. In the second approach, analyses were performed aiming for more precise infrasubspecific delineation from the partial sequences of the $g y r B$, $r p o D$, $f y u A$, dnaK, and $h r p B$ genes alone as well as from the concatenated sequence. In this second approach, only the isolates listed in Table 1 were analyzed. The inconsistency among the sequences of the concatenated genes in both approaches was evaluated with the phylogenetic analysis using parsimony (PAUP*) v. 4.0b10 software (Sowfford 2002) using the partition homogeneity test based on an analysis of the incongruence length difference (ILD) with 100 pseudoreplicates (bootstrap).

The individual and concatenated sequences were compared using maximum likelihood and Bayesian inference. The analyses were performed using models of nucleotide substitution selected by Akaike information criterion (AIC) using Mr. ModelTest 2.3 (Nylander 2004). The maximum likelihood analyses were performed via bootstrap of 1000 replicates using the PhyML 3.1 program (Guindon and Gascuel 2003). The Bayesian inference analyses were performed using the Mr. Bayes v. 3.2.6 (Ronquist et al. 2012) that is implemented in CIPRES server (https://www.phylo.org/portal2/home.action), with
100,000,000 generations of the Monte Carlo Markov chain, where sampling was performed every 1,000 generations, starting the process from a random tree.

Whole-genome DNA sequencing, assembly, calculation of ANI values, and TETRA coefficients. Standard DNA library preparation and genome sequencing was performed using the Illumina HiSeq 2500 platform at the Functional Genomics Center of the University of São Paulo. A paired-end (PE) DNA library was constructed with the Illumina Nextera XT DNA Library Prep Kit v4, and sequencing was performed on a HiSeq Flow Cell v4, with the HiSeq SBS Kit v4 and paired-reads 100 bp (2x). Initially, quality reads were analyzed by FastQC (Andrews 2010) and then the reads were treated by removing the adapters using FASTXToolkit (v. 0.0.13) (Hannon Lab 2014). Then, de novo assembly was performed with the trimmed reads data set using the SPAdes software (v. 1.10) (Bankevich et al. 2012).

The whole-genomes sequences of 117 strains belonging to different species of Xanthomonas genus available in the NCBI database were downloaded and analyzed along to the draft genomes of the strains LMG965 (=IBSBF1967PT) (accession numbers CBZT010000001 to

TABLE 1. Description of the Xanthomonas isolates used in this study

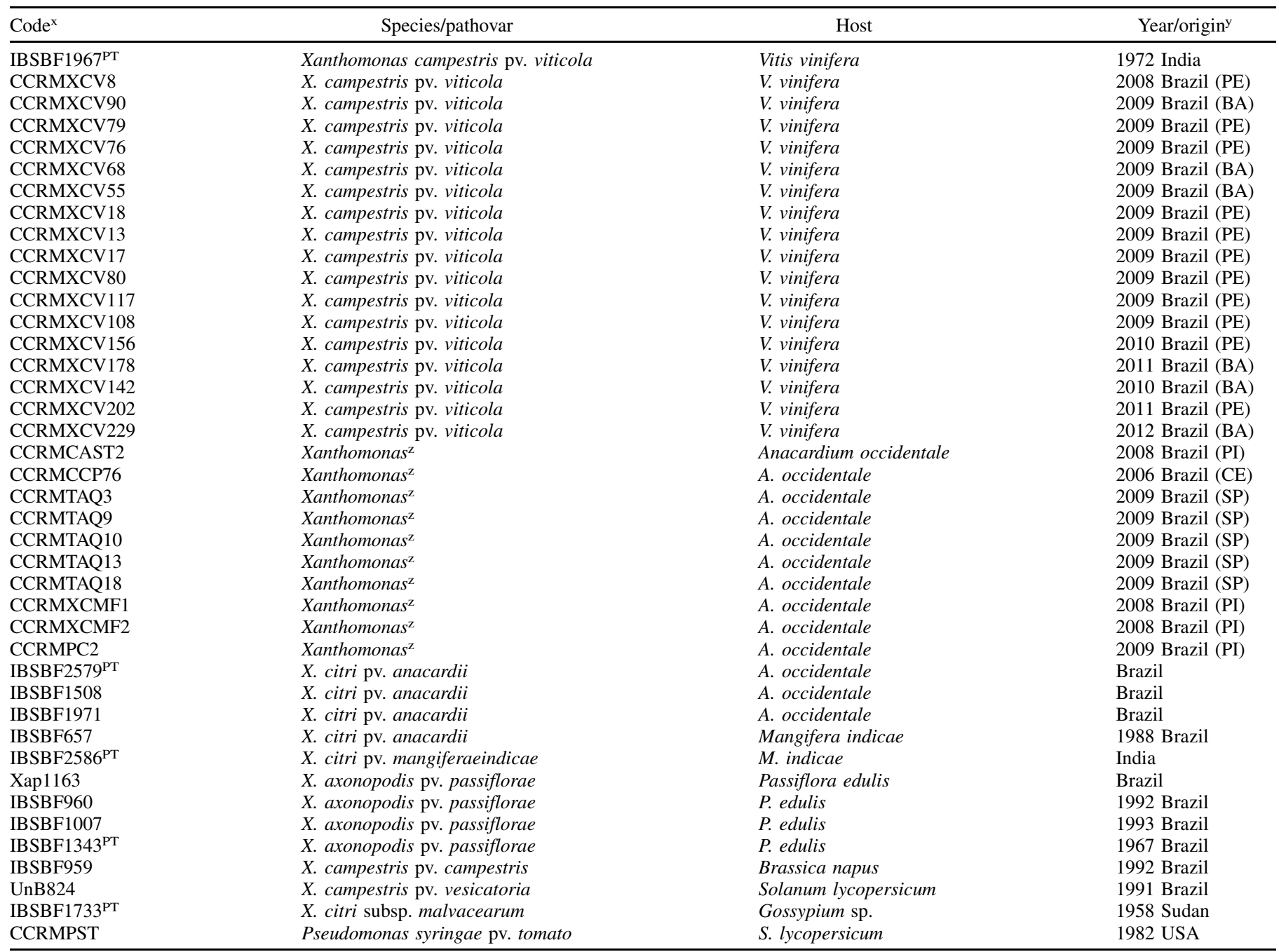

${ }^{\mathrm{x}}$ IBSBF1967 ${ }^{\text {PT }}$ (pathotype isolate) = ICMP3867, LMG965, and NCPPB2475; IBSBF2579PT = ICMP4088; IBSBF2586 ${ }^{\text {PT }}=$ ICMP5740, LMG941, NCPPB490, and ATCC11637; IBSBF959 = ICMP12188; IBSBF960 = ICMP12189; IBSBF1343 ${ }^{\text {PT }}=$ IMCP3151, LMG810, and NCPPB2346; IBSBF1733 ${ }^{\text {PT }}=$ ICMP5739 and LMG761; UnB824 = IBSBF905. IBSBF: Phytopathogenic Culture Collection of Instituto Biológico (São Paulo, Brazil); ICMP: International Collection of Microorganisms from Plants (Auckland, New Zealand); LMG: Belgian Coordinated Collections of Micro-Organisms (Ghent, Belgium); NCPPB: National Collection of Plant Pathogenic Bacteria (York, United Kingdom); UnB: Phytopathogenic Bacteria Collection of the Department of Phytopathology of the University of Brasília (Federal District, Brazil). CCRM = isolates from the Laboratory of Phytobacteriology (LAFIBAC) Culture Collection of Federal Rural University of Pernambuco-UFRPE (Pernambuco, Brazil).

y $\mathrm{BA}=$ Bahia state, $\mathrm{CE}=$ Ceará state, $\mathrm{PE}=$ Pernambuco state, $\mathrm{PI}=$ Piauí state, and $\mathrm{SP}=$ São Paulo state

z Pigmented isolates pathogenic to cashew plant. 
CBZT010000050) (Midha and Patil 2014) and CCRMXCV80 (accession number NWTJ01000000) (Lima et al. 2017) of X. campestris pv. viticola, the nonpigmented isolates CFBP2913 (accession number CP024057.1) and IBSBF2579PT (Silva et al. 2018) of X. citri pv. anacardii, and the pigmented isolates pathogenic to cashew plant, CCRMTAQ13 and CCRMTAQ18, sequenced for this study and deposited at DDBJ/ENA/GenBank under the accession number PESG01000000 and PESH01000000, respectively. The list of the complete genomes downloaded from the NCBI and the draft genome analyzed, and extra details is provided in the Supplementary Table S3. The sequences were used for ANI (ANIm) and TETRA calculations (Richter and Rosselló-Móra 2009) using the pyani 0.2.7 Python3 module (https://github.com/widdowquinn/ pyani) (Pritchard et al. 2016) obtained by whole-genome alignments through NUCmer (Kurtz et al. 2004).

Metabolic characterization. Metabolic characterization was performed using a Biolog System, Inc. (Hayward, CA) using Biolog GenIII microplates (71 carbon sources and 23 inhibitory substances) according to the manufacturer's recommendations. The isolates were cultured in BUG medium (Biolog Universal Growth) at $29^{\circ} \mathrm{C}\left( \pm 0.5^{\circ} \mathrm{C}\right)$ for $36 \mathrm{~h}$, and the suspensions were prepared in IF-A inoculation fluid, adjusting the transmittance to $95 \%$. Next, $150 \mu \mathrm{l}$ of the suspension was added to the microplate wells, which were incubated at $33^{\circ} \mathrm{C}$ for $36 \mathrm{~h}$. Visual evaluations were performed to observe the wells change color. The experiment was repeated to verify the generated profiles.

Pathological characterization. In separate experiments, five isolates of $X$. campestris pv. viticola (IBSBF1967PT, CCRMXCV17, CCRMXCV80, CCRMXCV117, and CCRMXCV178), five pigmented isolates pathogenic to cashew plant (CCRMTAQ3, CCRMTAQ13, CCRMTAQ18, CCRMXCMF1, and CCRMXCMF2), three isolates of $X$. citri pv. anacardii (IBSBF657, IBSBF1508, and IBSBF2579PT), and one isolate of $X$. citri pv. mangiferaeindicae (IBSBF2586 ${ }^{\mathrm{PT}}$ ) were inoculated on the following: (i) grape seedling leaves ( $V$. vinifera 'Red Globe'), and (ii) cashew leaves (clone CCP76). The concentrations of the bacterial suspensions were adjusted to $10^{8} \mathrm{CFU} / \mathrm{ml}$ using a spectrophotometer (Analyzer 500 M, São Paulo, Brazil) (Gama et al. 2011). The inoculation was performed into four points of a leaf blade (the first eight leaves of each seedling were used, starting at the apex) by infiltration of $100 \mu \mathrm{l}\left( \pm 10^{7} \mathrm{CFU}\right)$ of the suspensions with the aid of a needleless hypodermic syringe (Ah-You et al. 2007). Leaves inoculated with SDW alone comprised the negative control. The experiment was completely randomized with four replicates such that each replicate comprised one leaf with four inoculation points per isolate. After the inoculations, the seedlings were incubated in a greenhouse and evaluated daily for 12 days to determine the incubation period, which is the number of days from inoculation until the onset of the first symptoms. Disease severity was evaluated at 12 days after inoculation, estimating the extent of damage in diametrically opposite directions. The population sizes in leaf lesions from grape and cashew were estimated 13 days after inoculation for isolates CCRMXCV80, CCRMXCMF1, IBSBF2579PT, and IBSBF2586 ${ }^{\mathrm{PT}}$ as previously described (Ah-You et al. 2007). Four leaf fragments $\left(1 \mathrm{~cm}^{2}\right)$ were excised from the leaf blade, surface-sterilized and individually homogenized in $1 \mathrm{ml}$ of SDW. Aliquots of the homogenized suspensions and of 10-fold dilutions obtained from the suspensions were plated on NYDA media. Bacterial population sizes were based on enumeration of isolates colonies. The experiment was performed twice.

Considering that no significant $(P \leq 0.05)$ differences were observed regarding variance between the two experiments, the data were evaluated as replicates in time. The assumptions of the analysis of variance were verified by Shapiro-Wilk and Levene tests using the Statistix 9 software (Tallahassee, FL). The means were compared by the Scott-Knott test $(P \leq 0.05)$ using the SAEG program version 9.0 (Federal University of Viçosa-UFV, Viçosa, Minas Gerais, Brazil) and by the least significant difference test using the Statistix 9 program.

\section{RESULTS}

Molecular characterization. The grouping analysis of the 116 isolates of $X$. campestris pv. viticola performed by rep-PCR data (REP, ERIC, and BOX-PCR) enabled the formation of a single group comprising all of the $X$. campestris pv. viticola isolates at the $88 \%$ similarity level and bootstrap values of $100 \%$ (Supplementary Fig. S1). Seven subgroups were defined at a $90 \%$ similarity level: subgroup I comprised $81 \%$ of the isolates, including the pathotype isolate IBSBF1967PT and isolates collected in the states of Ceará (IBSBF2647), state unidentified (UnB1318), Paraná (4779-B), Roraima (BHV482), and São Paulo (IBSBF2738 and IBSBF2739); subgroup II consisted of isolates CCRMXCV13, CCRMXCV52, CCRMXCV178, and CCRMXCV208; subgroup III consisted of isolates CCRMXCV225, CCRMXCV79, CCRMXCV116, CCRMXCV156, and CCRMXCV206; subgroup IV consisted of isolates CCRMXCV229, CCRMXCV232, CCRMXCV228, and CCRMXCV205; subgroup V consisted of isolates CCRMXCV142 and CCRMXCV38; subgroup VI consisted of isolate CCRMXCV55; and subgroup VII consisted of isolates CCRMXCV171, CCRMXCV39, CCRMXCV5, CCRMXCV8, CCRMXCV117, and CCRMXCV68. No relationships were identified between the rep-PCR subgroups and the year, origin, organ, or cultivar from which the isolates were obtained.

Cluster analyses of the Xanthomonas species/pathovars listed in Table 1 using REP, ERIC, and BOX data alone (data not shown) linearly corroborated the analysis of the combined data, allowing for the formation of a single group containing all of the Xanthomonas isolates and the differentiation of $P$. syringae pv. tomato at $58 \%$ similarity and $100 \%$ bootstrap (Fig. 1). The following six groups were formed at $64 \%$ similarity: group I, comprising isolates of $X$. citri pv. mangiferaeindicae, X. campestris pv. viticola, and $X$. citri subsp. malvacearum; group II, comprising pigmented isolates pathogenic to cashew plant and $X$. citri pv. anacardii; group III, comprising $X$. vesicatoria; group IV, comprising isolates of $X$. axonopodis pv. passiflorae; group $\mathrm{V}$, comprising $X$. campestris pv. campestris; and group VI, comprising $P$. syringae pv. tomato. Additionally, the groups I, II, and III found in this study corresponded with the groups 9.5, 9.6, and 9.2 of $X$. axonopodis sensu Rademaker et al. (2005), respectively.

Phylogenetic characterization. In the first approach performed with the Xanthomonas isolates used in this study (Table 1), together with 23 Xanthomonas species retrieved from the GenBank database, the phylogenetic trees constructed based on the partial sequences of the $g y r B, r p o D, f y u A$, and dnaK genes analyzed separately exhibited similar structures using the maximum likelihood and Bayesian inference methods. The ILD analysis demonstrated that those trees generated with individual sequences of the gyr $B, r p o D, f y u A$, and $d n a K$ genes were highly consistent with the trees generated with the concatenated sequence $(P=0.01)$. The phylogenetic trees generated with the concatenated sequence $(3,376$ nucleotides) using the two methods cited also exhibited similar structures. A phylogenetic tree obtained using Bayesian inference with the general time reversible (GTR) model with gamma variation $(\mathrm{G})$ and proportions of invariable sites (I) provided one true reproduction of the current taxonomic positions of the species and pathovars of Xanthomonas (Fig. 2). Two groups were formed as previously described by Hauben et al. (1997) and Young et al. (2008). Additionally, subgroups 9.1 to 9.6 of $X$. axonopodis sensu Rademaker et al. (2005) were satisfactorily reproduced.

The isolates of $X$. campestris pv. viticola (CCRMXCV17, CCRMXCV80, CCRMXCV117, and IBSBF1967PT) and pigmented isolates pathogenic to cashew plant (CCRMTAQ13, CCRMTAQ18, and IBSBF2579PT) clustered in the groups 9.5 and 9.6 of $X$. axonopodis sensu Rademaker et al. (2005), respectively, and within phylogenetic group I (PGI), subgroup 2 sensu Constantin et al. (2016).

In the second approach performed with the Xanthomonas isolates used in this study (Table 1), the phylogenetic trees constructed 
based on the partial sequences of the genes gyrB, rpoD, fyuA, dnaK, and $h r p B$ analyzed separately exhibited similar structures using the maximum likelihood and Bayesian inference methods. Additionally, the individual analysis of the five genes was able to reproduce subgroups 9.2, 9.4, 9.5, and 9.6 of $X$. axonopodis regardless of the method selected, although only the $h r p B$ gene was able to delineate infra-subspecific relationships.
The ILD analysis demonstrated that the sequences of the $g y r B$, $r p o D$, fyuA, dnaK, and $h r p B$ genes (4,107 nucleotides) were highly inconsistent with the concatenated sequence $(P=0.35)$. The phylogenetic tree generated with the partial sequence of the $h r p B$ gene by Bayesian inference with the GTR model and proportions of invariable sites (I) placed the isolates of $X$. campestris pv. viticola in subgroup 9.5 and the pigmented isolates pathogenic to cashew plant

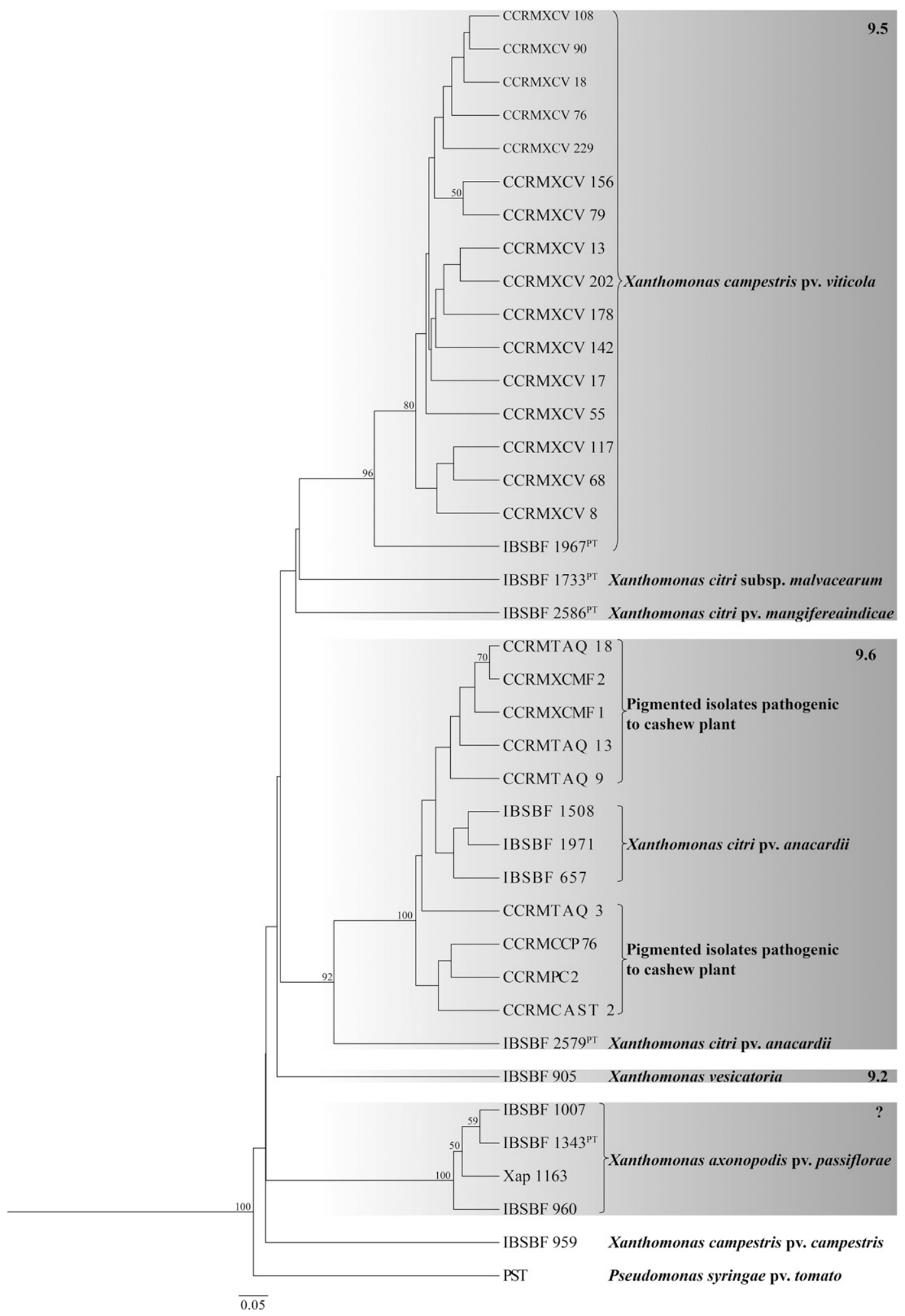

Fig. 1. Dendrogram based on the unweighted pair group method with arithmetic mean method according to the profiles generated using rep-PCR (ERIC, REP, and BOX-PCR) showing the genetic relationships among the species and pathovars of Xanthomonas used in this study. The bar indicates 5\% difference in the genomic profiles. The positions of Xanthomonas campestris pv. viticola and the pigmented isolates pathogenic to cashew in subgroups 9.5 and 9.6 Xanthomonas axonopodis sensu Rademaker et al. (2005) are shown. Bootstrap values lower than 50\% are not shown on the branches. 
in subgroup 9.6 (Fig. 3). However, in subgroup 9.5, all of the isolates of $X$. campestris pv. viticola grouped separately from the isolates of $X$. citri pv. mangiferaeindicae (IBSBF2586 ${ }^{\mathrm{PT}}$ ) and $X$. citri subsp. malvacearum (IBSBF1733 ${ }^{\mathrm{PT}}$ ) with values above $99 \%$ posterior probability. Similarly, in subgroup 9.6, all of the pigmented isolates pathogenic to cashew plant (CCRMCAST2, CCRMCCP76, CCRMTAQ3, CCRMTAQ9, CCRMTAQ10, CCRMTAQ13,
CCRMTAQ18, CCRMXCMF1, CCRMXCMF2, and CCRMPC2) grouped separately from the isolates of $X$. citri pv. anacardii with values above $99 \%$ posterior probability, indicating the branch's high reliability.

Whole genome sequence analysis. The ANI and TETRA data showed that isolates of $X$. campestris pv. viticola should not be classified as $X$. campestris. ANI values between the isolates of

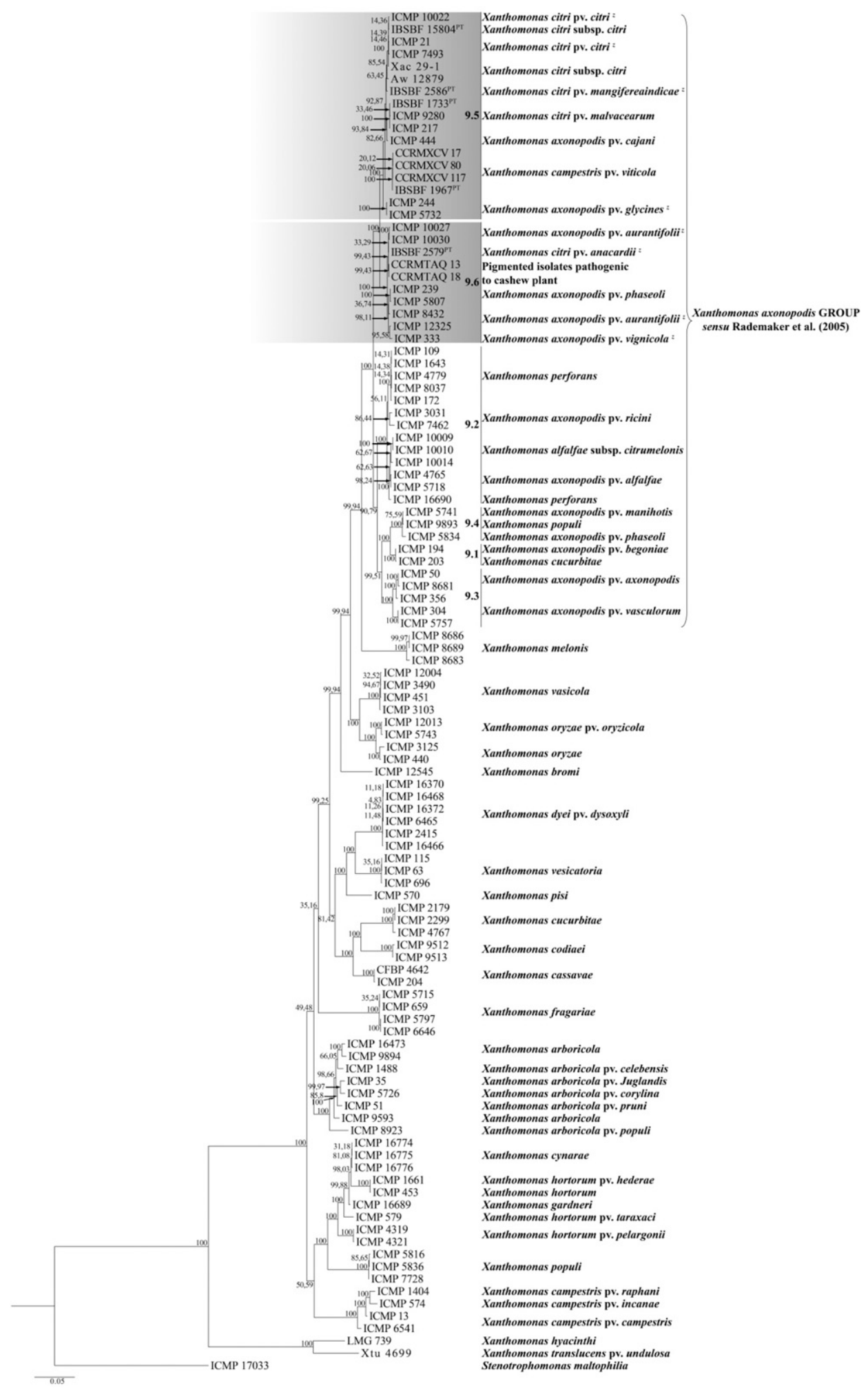

Fig. 2. Multilocus sequence analysis performed by Bayesian inference from the partial sequences of the $\operatorname{gyr} B$, $r p o D$, fyuA, and $d n a K$ genes. The bar indicates the number of substitutions per site. The positions of Xanthomonas campestris pv. viticola and the pigmented isolates pathogenic to cashew plant in subgroups 9.5 and 9.6 of Xanthomonas axonopodis sensu Rademaker et al. (2005) are shown. Posterior probability values are shown on the branches and indicated by arrows. $\mathrm{z}$ indicates isolates reclassified by Constantin et al. (2016). 
$X$. campestris pv. viticola $\left[\left(\mathrm{LMG} 965^{\mathrm{PT}}=\mathrm{IBSBF} 1967^{\mathrm{PT}}\right)\right.$ and CCRMXCV80] and the type isolate of $X$. campestris pv. campestris (ATCC $33913^{\mathrm{PT}}$ ) were below $88 \%$ (data not shown). On the other hand, ANI values and TETRA coefficients between the isolates of $X$. campestris pv. viticola and $X$. citri pathovars were always above $96 \%$ and 0.99 , respectively. We observed ANI values of 98.9 and 98.9\% and TETRA coefficients of 0.999 and 0.995 between the isolates of $X$. campestris pv. viticola (IBSBF1967PT and CCRMXCV80) and the pathotype isolate of $X$. citri pv. mangiferaeindicae (LMG $\left.941^{\mathrm{PT}}=\mathrm{IBSBF} 2586^{\mathrm{PT}}\right)$, respectively. ANI values of 98.9 and $98.9 \%$ and TETRA coefficients of 0.999 and 0.996 were observed between the isolates of $X$. campestris pv. viticola (IBSBF1967 $7^{\mathrm{PT}}$ and CCRMXCV80) and the type isolate of $X$. citri subsp. citri (LMG 9322 ), respectively. In turn, ANI values of 96.3 and $96.3 \%$ and TETRA coefficients of 0.997 and 0.992 were detected between X. campestris pv. viticola (IBSBF1967PT and CCRMXCV80) and $X$. citri pv. aurantifolii (strain 1566), respectively.

ANI values and TETRA coefficients between pigmented isolates pathogenic to cashew plant (CCRMTAQ13 and CCRMTAQ18) and $X$. citri pathovars were always above $96 \%$ and 0.99 , respectively (data not shown). We observed ANI values of 99.5 and $99.5 \%$ and TETRA coefficients of 0.999 and 0.999 between the pigmented isolates pathogenic to cashew plant (CCRMTAQ13 and CCRMTAQ18) and the pathotype isolate of $X$. citri pv. anacardii (IBSBF2579PT), while ANI values of 96.3 and $96.4 \%$ and TETRA coefficients of 0.994 and 0.997 were detected between the pigmented isolates pathogenic to cashew plant and the pathotype isolate of $X$. citri pv. mangiferaeindicae (IBSBF2586 ${ }^{\mathrm{PT}}$ ).

Metabolic characterization. The reactions of Xanthomonas isolates analyzed in this study are represented by the percentage of isolates with positive, negative or variable reactions for each of the 94 biochemical tests contained in the Biolog Gen III microplates system (Supplementary Table S4). All isolates of X. campestris pv. viticola showed $100 \%$ positive reactions for L-malic acid, citric acid, $\alpha$-keto-glutaric acid, D-cellobiose, D-fructose, D-galactose, D-mannose, D-trehalose, gentiobiose, L-fucose, $N$-acetyl-D-glucosamine, $1 \% \mathrm{NaCl}$, pectin, $\mathrm{pH} 6$, sucrose, Tween 40 , and $\alpha$-D-glucose and negative reactions for D-aspartic acid, D-malic acid, formic acid, fusidic acid,
L-galactonic acid lactone, $N$-acetyl-D-galactosamine, $N$-acetyl neuraminic acid, $\gamma$-amino-butyric acid, sodium bromate, sodium butyrate, lithium chlorite, D-arabitol, D-mannitol, D-serine, L-serine, D-sorbitol, $\alpha$-D-lactose, guanidine $\mathrm{HCl}$, minocycline, myo-inositol, $4 \% \mathrm{NaCl}, 8 \%$ $\mathrm{NaCl}$, Niaproof 4 , potassium tellurite, troleandomycin, and $\beta$-methylD-glucoside.

All pigmented isolates pathogenic to cashew plant and isolates of $X$. citri pv. anacardii showed $100 \%$ positive reactions for L-malic acid, acetic acid, citric acid, L-glutamic, D-cellobiose, dextrin, D-fructose, D-galactose, D-trehalose, L-fucose, $N$-acetylD-glucosamine, pectin, $\mathrm{pH} 6$, sucrose, and $\alpha$-D-glucose and negative reactions for D-aspartic acid, D-malic acid, fusidic acid, L-galactonic acid lactone, L-pyroglutamic, $N$-acetyl-D-galactosamine, $\mathrm{N}$-acetyl neuraminic acid, nalidixic acid, p-hydroxy-phenylacetic acid, quinic acid, $\beta$-hydroxy- D,L-butyric acid, $\gamma$-amino-butyric acid, sodium bromate, sodium butyrate, lithium chlorite, D-mannitol, D-serine, L-serine, D-sorbitol, stachyose, guanidine $\mathrm{HCl}$, L-arginine, L-histidine, minocycline, myo-inositol, $4 \% \mathrm{NaCl}, 8 \% \mathrm{NaCl}$, Niaproof 4 , potassium tellurite, troleandomycin, vancomycin, and $\beta$-methylD-glucoside. These isolates showed the same reaction in approximately $65 \%$ of substrates analyzed.

Pathological characterization. Only isolates of $X$. campestris pv. viticola were able to cause damage to grape leaves of cultivar Red Globe. However, no significant $(P<0.05)$ differences were observed among the isolates for the variables analyzed (data not shown). Population density of isolate CCRMXCV108 on grape cultivar Red Globe was $5.3 \times 10^{6} \mathrm{CFU}$ per lesion (data not shown).

All of the isolates were able to cause damage to the cashew leaves. The cluster analysis performed with the epidemiologic data allowed for identification of two groups (A and B) based on the incubation period: group A, comprising two isolates of $X$. campestris $\mathrm{pv}$. viticola and one isolate of $X$. citri pv. anacardii with an incubation period of 4.0 to 4.3 days, and group B, comprising the other isolates with an incubation period of 2.5 to 3.5 days (Table 2). Six groups were identified (A to F) based on the disease severity data: group A, comprising two pigmented isolates pathogenic to cashew plant with a severity of 6.9 to $7.4 \mathrm{~mm}$; group $\mathrm{B}$, comprising one pigmented isolated pathogenic to cashew plant with a severity of $5.8 \mathrm{~mm}$; group

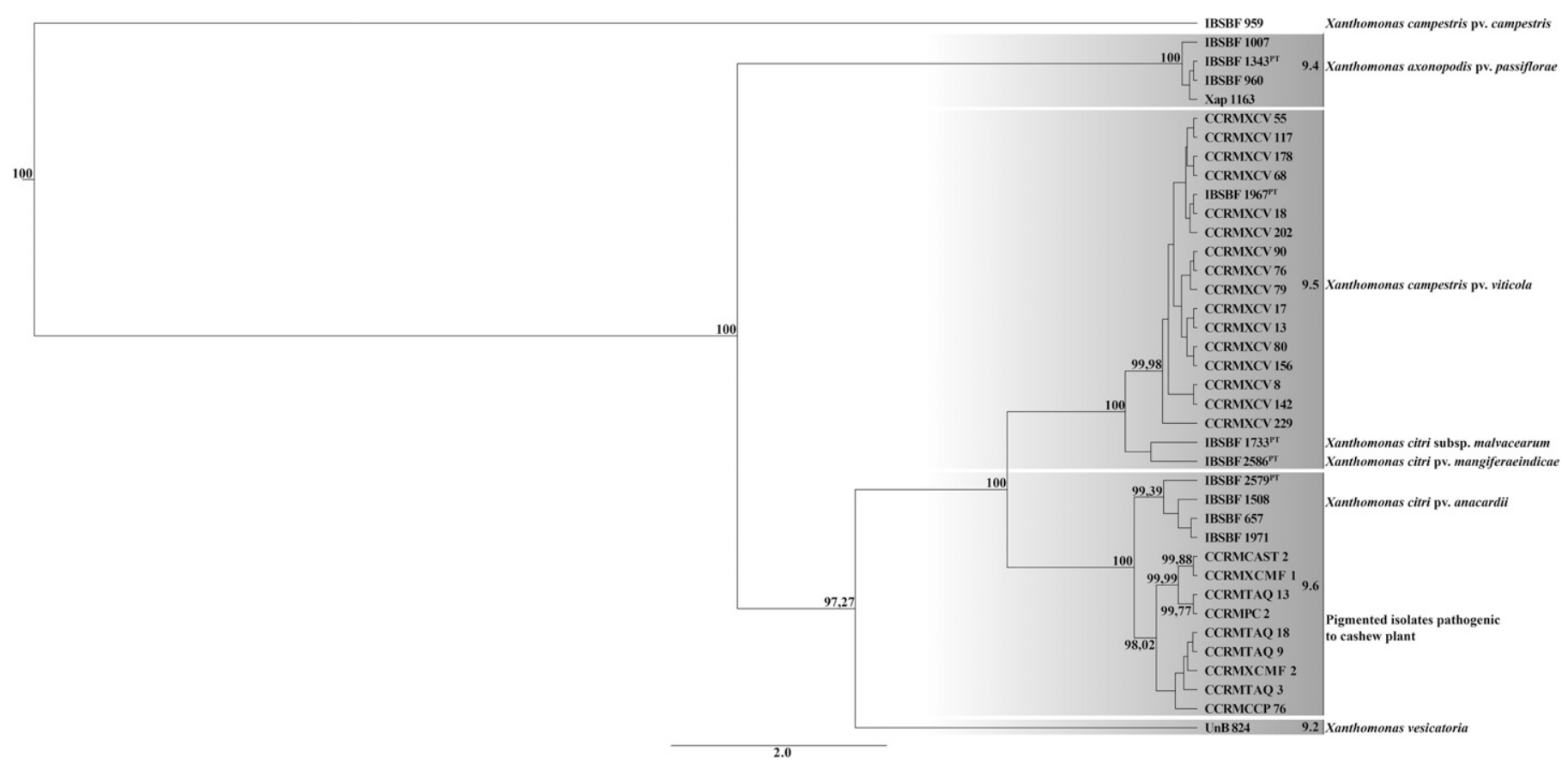

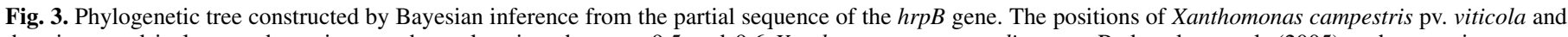

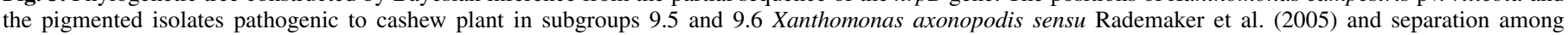

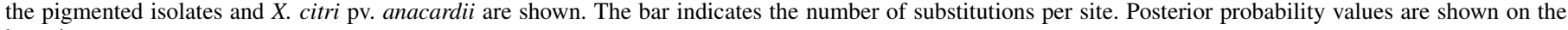
branches. 
cashew plant and $X$. citri pv. anacardii were analyzed based on the partial sequence of the $h r p B$ gene alone. The resulting phylogenetic tree generated by Bayesian inference allowed for satisfactory separation among the pigmented isolates pathogenic to cashew plant and the isolates of $X$. citri pv. anacardii. These results suggest substantial differences with respect to host range or aggressiveness against different hosts. However, considering that previous studies have demonstrated that pigmented isolates pathogenic to cashew plant and $X$. citri $\mathrm{pv}$. anacardii are equally aggressive to the cashew plant (Gama et al. 2011), it is most likely that these differences can only be detected via epidemiologic studies conducted with a broad host range.

To confirm the significance of the MLSA tree in the evolutionary relationship of the species of the genus Xanthomonas, we used drafts and complete available genomes of the Xanthomonas genus. The ANI data and the TETRA correlation coefficients showed that strains of $X$. campestris pv. viticola should be classified as a pathovar of $X$. citri because the ANI values and TETRA correlation coefficients between these isolates were always above $96 \%$ and 0.99 , and the ANI value and TETRA correlation coefficients used for species delineation cut-off is below of $95 \%$ (Goris et al. 2007) and 0.99 (Richter and Rosselló-Móra 2009), respectively.

ANI and TETRA correlation coefficients values between pigmented isolates pathogenic to cashew plant (CCRMTAQ13 and CCRMTAQ18) and X. citri pv. anacardii (CFBP 2913 and IBSBF 2579) and within these isolates were always above $99 \%$ and 0.99. Thus, these data confirmed the result obtained by MLSA, which showed a close relationship among the pigmented isolates pathogenic to cashew plant and $X$. citri pv. anacardii. These data indicate that the pigmented isolates pathogenic to cashew plant should also be classified as $X$. citri pv. anacardii.

Biolog Microplate System has been successfully used to characterize metabolic diversity between the species of genus Xanthomonas (Vauterin et al. 1995) and within species/pathovars of this genus (Constantin et al. 2016; Stoyanova et al. 2014; Verniere et al. 1993). In general, the analysis of Xanthomonas isolates by Biolog Microplate System show that some substrates can be useful as markers to differentiate species/pathovars for the purposes of the routine identification. For example, Verniere et al. (1993) reported that the substrates L-fucose, D-galactose, and alaninamide were useful to differentiate isolates of $X$. citri pathogenic to citrus. Despite the high metabolic similarity observed among the Xanthomonas isolates analyzed in this study, some tests exhibited high discriminatory power, and thus, combining them may be used in differentiating the species/pathovars. All of the pigmented isolates pathogenic to cashew plant and the isolate of $X$. citri pv. mangiferaeindicae exhibited a positive reaction for $\mathrm{L}$-aspartic acid and a negative reaction for Rifamycin SV while all isolates of $X$. citri pv. anacardii showed a negative reaction for L-aspartic acid and a positive reaction for Rifamycin SV. As for using $\gamma$-aminobutyric acid as a carbon source, the pigmented isolates pathogenic to cashew plant and $X$. citri $\mathrm{pv}$. anacardii exhibited a negative reaction while $X$. citri pv. mangiferaeindicae showed a positive reaction. Similar results were reported by Pruvost et al. (1998), who observed that isolates of $X$. citri pathogenic to Anacardiaceae exhibited a positive reaction for $\gamma$-amino-butyric acid and Rifamycin SV. However, in contrast to the results obtained in this study, Pruvost et al. (1998) detected variations among isolates for L-aspartic acid.

All the isolates of $X$. campestris pv. viticola and isolates pathogenic to cashew plant were pathogenic to the cashew plant clone CCP76. The five groups (A to E) formed by pigmented isolates pathogenic to cashew plant and $X$. citri pv. anacardii, identified in previous studies based on the severity of leaf damage caused by artificial inoculations (Gama et al. 2011), were confirmed. All isolates of $X$. campestris pv. viticola were inside the less aggressive groups (groups $\mathrm{E}$ and $\mathrm{F}$ of severity) and the population density of the isolate CCRMXCV80 was significantly lower than those obtained for pigmented isolate pathogenic to cashew plant,
$X$. citri pv. anacardii and $X$. citri pv. mangiferaeindicae, indicating low aggressiveness of these isolates to the cashew plant. In turn, the pigmented isolates pathogenic to cashew plant exhibited shorter incubation periods, higher severity values and higher population density, indicating higher aggressiveness of these isolates against the cashew plant, as previously demonstrated (Gama et al. 2011). In contrast, only isolates of $X$. campestris pv. viticola were pathogenic on the leaves of grapevine cultivar Red Globe, showing high population density $\left(5.3 \times 10^{6} \mathrm{CFU}\right.$ per lesion). This information is important for differentiating and characterizing these isolates because $X$. campestris pv. viticola, pigmented isolates pathogenic to cashew plant, $X$. citri pv. anacardii and $X$. citri pv. mangiferaeindicae were pathogenic to cashew plants, but only X. campestris pv. viticola was able to cause lesions on the grapevine leaves.

It was clearly demonstrated that $X$. campestris pv. viticola was placed in subgroup 9.5 of $X$. axonopodis sensu Rademaker et al. (2005) and within PGI, subgroup 2, sensu Constantin et al. (2016), which are currently composed by X. citri pathovars. X. campestris pv. viticola was closely related to $X$. citri $\mathrm{pv}$. mangiferaeindicae (rep-PCR, MLSA, ANI, and TETRA) and X. citri subsp. citri (MLSA, ANI, and TETRA). Consequently, it is suggested that $X$. campestris pv. viticola be reclassified as $X$. citri $\mathrm{pv}$. viticola comb. nov. In turn, pigmented isolates pathogenic to cashew plant were closely related to $X$. citri pv. anacardii (rep-PCR, MLSA, ANI, TETRA, and pathological characteristics). Thus, pigmented isolates pathogenic to cashew plant should also be classified as $X$. citri pv. anacardii.

Description of $X$. citri pv. viticola (Nayudu 1972) Dye 1978 comb. nov. Based on rep-PCR, MLSA using sequences of the housekeeping genes $g y r B, r p o D$, fyuA, and $d n a K$; sequencing and phylogenetic analysis of the $h r p B$ gene for the pathogenicity and hypersensitive response; and ANI values and TETRA correlation coefficients, the bacterium is genetically related to pathovars of $X$. citri sensu Constantin (Constantin et al. 2016). Isolates of $X$. citri pv. viticola can be readily distinguished from another pathovars of $X$. citri by rep-PCR analysis, MLSA, ANI values and TETRA coefficient. Its genome contains G-C content of $63.84 \%$ and approximately 4,427 genes (Lima et al. 2017). Isolates of $X$. citri pv. viticola produce nonpigmented (creamy white) colonies when cultivated on NYDA medium, and on Biolog GEN III MicroPlate System show $100 \%$ positive reaction for L-malic acid, citric acid, $\alpha$-keto-glutaric acid, D-cellobiose, D-fructose, D-galactose, D-mannose, D-trehalose, gentiobiose, L-fucose, $\mathrm{N}$ acetyl-D-glucosamine, $1 \% \mathrm{NaCl}$, pectin, $\mathrm{pH}$ 6, sucrose, Tween 40, and $\alpha$-D-glucose and negative reaction for D-aspartic acid, D-malic acid, formic acid, fusidic acid, L-galactonic acid lactone, $N$-acetylD-galactosamine, $N$-acetyl neuraminic acid, $\gamma$-amino-butyric acid, sodium bromate, sodium butyrate, lithium chlorite, D-arabitol, D-mannitol, D-serine, D-serine, D-sorbitol, $\alpha$-D-lactose, guanidine $\mathrm{HCl}$, minocycline, myo-inositol, $4 \% \mathrm{NaCl}, 8 \% \mathrm{NaCl}$, Niaproof 4 , potassium tellurite, troleandomycin, and $\beta$-methyl- D-glucoside. $X$. citri pv. viticola affects all aerial parts of the grapevine plant. The most common symptoms of disease are cankers on the twigs, branches, petioles and veins. Leaf symptoms begin as small watersoaked spots delineated by veins, becoming dark lesions, with or without a chlorotic halo. Sometimes the veins and surrounding tissues can exhibit dark spots. Berries symptoms appear as several depressed dark lesions. In some cases, an exudation can be observed over the lesions. Elevated population sizes $\left( \pm 5 \times 10^{6} \mathrm{CFU}\right.$ per lesion) can be recovered from grapevine leaf lesions. The pathotype isolate is IBSBF 1967 PT (Phytopathogenic Culture Collection of Instituto Biológico, Brazil) = LMG 965 ${ }^{\mathrm{PT}}$ (Belgian Coordinated Collections of Microorganisms, University of Ghent, Belgium) = NCPPB 2475 ${ }^{\mathrm{PT}}$ (National Collection of Plant Pathogenic Bacteria, $\mathrm{UK})=\mathrm{CFBP} 7660^{\mathrm{PT}}$ (Collection Française de Bactéries associées aux Plantes/CIRM-CFBP, France).

Emended description of $X$. citri pv. anacardii (Ah-You et al. 2007) emend. (Constantin et al. 2016). Description of 
Ah-You et al. (2007) and Constantin et al. (2016) extended to include yellow-pigmented isolates pathogenic to cashew plant (this study). Based on Biolog GEN III MicroPlate System, yellowpigmented isolates show reaction positive for $\mathrm{L}$-aspartic acid and negative reaction for Rifamycin SV, while nonpigmented isolates show negative reaction for L-aspartic acid and positive reaction for Rifamycin SV. The pathotype isolate is IBSBF2579PT (Phytopathogenic Culture Collection of Instituto Biológico, Brazil) $=$ CFBP $2913^{\text {PT }}$ (Collection Française de Bactéries associées aux Plantes, France $)=$ ICMP $4088^{\mathrm{PT}}$ (International Collection of Micro-organisms from Plants, New Zealand).

\section{ACKNOWLEDGMENTS}

We thank O. Pruvost for manuscript review before submission.

\section{LITERATURE CITED}

Ah-You, N., Gagnevin, L., Chiroleu, F., Juen, E., Rodrigues Neto, J., and Pruvost, O. 2007. Pathological variations within Xanthomonas campestris pv. mangiferaeindicae supported its separation into three distinct pathovars that can be distinguished by amplified fragment length polymorphism. Phytopathology 97:1568-1577.

Ah-You, N., Gagnevin, L., Grimont, P. A. D., Brisse, S., Nesme, X., Chiroleu, F., Bui Thi Ngoc, L., Juen, E., Lefeuvre, P., Vernière, C., and Pruvost, O. 2009. Polyphasic characterization of xanthomonads pathogenic to members of the Anacardiaceae and their relatedness to species of Xanthomonas. Int. J. Syst. Evol. Microbiol. 59:306-318.

Andrews, S. 2010. FastQC: A quality control tool for high throughput sequence data. Babraham Bioinformatics. http://www.bioinformatics.babraham. ac.uk/projects/fastqc

Araujo, J. S. P., Reis Júnior, F. B., Cruz, G. B., Oliveira, B. C., Robbs, C. F., Ribeiro, R. L. D., and Polidoro, J. C. 2005. Produção e caracterização de anticorpos policlonais contra Xanthomonas campestris pv. viticola. Pesqui. Agropecu. Bras. 40:305-309.

Bankevich, A., Nurk, S., Antipov, D., Gurevich, A. A., Dvorkin, M., Kulikov, A. S., Lesin, V. M., Nikolenko, S. I., Pham, S., Prjibelski, A. D., Pyshkin, A. V., Sirotkin, A. V., Vyahhi, N., Tesler, G., Alekseyev, M. A., and Pevzner, P. A. 2012. SPAdes: A new genome assembly algorithm and its applications to single-cell sequencing. J. Comput. Biol. 19:455-477.

Bansal, K., Midha, S., Kumar, S., and Patil, P. B. 2017. Ecological and evolutionary insights into Xanthomonas citri pathovar diversity. Appl. Environ. Microbiol. 83:e2993-e16.

Brazil Ministério da Agricultura, Pecuária e Abastecimento. 2001. Secretaria de Defesa Agropecuária. Instrução Normativa N 20 de 27 de setembro de 2001. Aprova as diretrizes para a produção integrada de frutas-DGPIF e as normas técnicas gerais para a produção integrada de frutas. http://sistemasweb.agricultura. gov.br/sislegis/action/detalhaAto.do?method=visualizarAtoPortalMapa\&chave= 730995312

Breed, R. S., Murray, E. G. D., and Smith, N. R. 1957. Bergey's Manual of Determinative Bacteriology, 7th Ed. The Williams and Wilkins Company, Baltimore, MA.

Bull, C. T., De Boer, S. H., Denny, T. P., Firrao, G., Fischer-Le Saux, M., Saddler, G. S., Scortichini, M., Stead, D. E., and Takikawa, Y. 2010. Comprehensive list of names of plant pathogenic bacteria, 1980-2007. J. Plant Pathol. 92:551-592.

Castillo, J. A., and Greenberg, J. T. 2007. Evolutionary dynamics of Ralstonia solanacearum. Appl. Environ. Microbiol. 73:1225-1238.

Constantin, E. C., Cleenwerck, I., Maes, M., Baeyen, S., Van Malderghem, C., De Vos, P., and Cottyn, B. 2016. Genetic characterization of strains named as Xanthomonas axonopodis pv. dieffenbachiae leads to a taxonomic revision of the $X$. axonopodis species complex. Plant Pathol. 65:792-806.

Doidge, E. 1915. A bacterial disease of the mango, Bacillus mangiferae n. sp. Ann. Appl. Biol. 2:1-45.

Edgar, R. C. 2004. Muscle: Multiple sequence alignment with high accuracy and high throughput. Nucleic Acids Res. 32:1792-1797.

Ferreira-Tonin, M. 2012. Caracterização taxonômica de espécies do gênero Xanthomonas. Ph.D. Thesis, Universidade Estadual de Campinas, Campinas, São Paulo.

Ferreira-Tonin, M., Corrêa, D. B. A., and Destéfano, S. A. L. 2011. Classificação de linhagens de Xanthomonas sp. por multilocus sequence analysis (MLSA) e Hibridização DNA-DNA. Trop. Plant Pathol. 36:128.

Food and Agriculture Organization of the United Nations. 2018. FAOSTAT. Roma. http://www.fao.org/faostat/en/\#data/QC/visualize

Gama, M. A. S., Mariano, R. L. R., Viana, F. M. P., Ferreira, M. A. S. V., and Souza, E. B. 2011. Polyphasic characterization of pigmented isolates of Xanthomonas pathogenic to cashew trees. Plant Dis. 95:793-802.
Goris, J., Konstantinidis, K. T., Klappenbach, J. A., Coenye, T., Vandamme, P., and Tiedje, J. M. 2007. DNA-DNA hybridization values and their relationship to whole-genome sequence similarities. Int. J. Syst. Evol. Microbiol. 57:81-91.

Guindon, S., and Gascuel, O. 2003. A simple, fast, and accurate algorithm to estimate large phylogenies by maximum likelihood. Syst. Biol. 52:696-704.

Hampl, V., Pavlicek, A., and Flegr, J. 2001. Construction and bootstrap analysis of DNA fingerprinting-based phylogenetic trees with the freeware program FreeTree: Application to trichomonad parasites. Int. J. Syst. Evol. Microbiol. 51:731-735.

Hannon Lab. 2014. FASTX toolkit. Cold Spring Harbor Laboratory, Cold Spring Harbor, NY. http://hannonlab.cshl.edu/fastx_toolkit/

Hauben, L., Vauterin, L., Swings, J., and Moore, E. R. B. 1997. Comparison of $16 \mathrm{~S}$ ribosomal DNA sequences of all Xanthomonas species. Int. J. Syst. Bacteriol. 47:328-335.

Instituto Brasileiro de Geografia e Estatística. 2018. SIDRA. Rio de Janeiro. https://www.ibge.gov.br/estatisticas-novoportal/economicas/agricultura-epecuaria/9117-producao-agricola-municipal-culturas-temporarias-e-permanentes. html?edicao $=16787 \& \mathrm{t}=$ resultados

Kurtz, S., Phillippy, A., Delcher, A. L., Smoot, M., Shumway, M., and Antonescu, C. 2004. Versatile and open software for comparing large genomes. Genome Biol. 5:R12.

Lazzarotto, J. J., and Fioravanço, J. C. 2013. Tendências e sazonalidades nas exportações e importações brasileiras de uva de mesa. Inf. Econ. 43:43-58.

Leite, R. P., Jr., Minsavage, G. V., Bonas, U., and Stall, R. E. 1994. Detection and identification of phytopathogenic Xanthomonas isolates by amplification of DNA sequences related to the hrp genes of Xanthomonas campestris pv. vesicatoria. Appl. Environ. Microbiol. 60:1068-1077.

Lima, N. B., Gama, M. A. S., Mariano, R. L. R., Silva, W. J., Jr., Farias, A. R. G., Falcão, R. M., Sousa-Paula, L. C., Benko-Iseppon, A. M., Paiva, S. S. L., Jr., Balbino, V. Q., and Souza, E. B. 2017. Complete genome sequence of Xanthomonas campestris pv. viticola strain CCRMXCV 80 from Brazil. Genome Announc. 5:e01263-e17.

Lopes, P. R. C., Oliveira, I. V. M., and Silva, R. R. S. 2009. Avaliação do potencial de produção de frutas de clima temperado no Nordeste Brasileiro. Semana internacional da fruticultura, floricultura e agroindústria, 16. Instituto Frutal, Fortaleza, Ceará.

Louws, E. J., Fulbright, D. W., Stephens, C. T., and Bruijn, F. J. 1994. Specific genomic fingerprints of phytopathogenic Xanthomonas and Pseudomonas pathovars and isolates generated with repetitive sequences and PCR. Appl. Environ. Microbiol. 60:2286-2295.

Marques, E. 2007. Variabilidade e tolerância ao cobre em Xanthomonas campestris pv. viticola agente causal do cancro bacteriano da videira Vitis spp. M.S. dissert. Universidade de Brasília, Brasília.

Midha, S., and Patil, P. B. 2014. Genomic insights into the evolutionary origin of Xanthomonas axonopodis pv. citri and its ecological relatives. Appl. Environ. Microbiol. 80:6266-6279.

Nayudu, M. V. 1972. Pseudomonas viticola sp. nov., incitant of a new bacterial disease of grapevine. Phytopathol. Z. 73:183-186.

Nylander, J. 2004. MrModeltest V2. Program Distributed by the Author. Uppsala University, Evolutionary Biology Centre.

Parkinson, N., Cowie, C., Heeney, J., and Stead, D. 2009. Phylogenetic structure of Xanthomonas determined by comparison of gyrB sequences. Int. J. Syst. Evol. Microbiol. 59:264-274.

Patel, M. K., Kulkarni, Y. S., and Moniz, L. 1948a. Pseudomonas mangiferaeindicae, pathogenic on mango. Indian Phytopathol. 1:147-152.

Patel, M. K., Moniz, L., and Kulkarni, Y. S. 1948b. A new bacterial disease of Mangifera indica L. Curr. Sci. 6:189-190.

Pavlicek, A., Hrdá, S., and Flegr, J. 1999. FreeTree-freeware program for construction of phylogenetic trees on the basis of distance data and bootstrap/ jacknife analysis of the robustness. Application in the RAPD analysis of genus Frekelia. Folia Biol. 45:97-99.

Perez-Losada, M., Viscidi, R. P., Demma, J. C., Zenilman, J., and Crandall, K. A. 2005. Population genetics of Neisseria gonorrhoeae in a highprevalence community using a hypervariable outer membrane porB and 13 slowly evolving housekeeping genes. Mol. Biol. Evol. 22:1887-1902.

Pritchard, L., Glover, R. H., Humphris, S., Elphinstone, J. G., and Toth, I. K. 2016. Genomics and taxonomy in diagnostics for food security: Soft rotting enterobacterial plant pathogens. Anal. Methods 8:12-24.

Pruvost, O., Couteau, A., Perrier, X., and Luisetti, L. 1998. Phenotypic diversity of Xanthomonas sp. mangiferaeindicae. J. Appl. Microbiol. 84:115-124.

Rademaker, J. L. W., Hoste, B., Lowus, F. J., Kersters, K., Swings, J., Vauterin, L., Vauterin, P., and Bruijn, F. L. 2000. Comparison of AFLP and rep-PCR genomic fingerprinting with DNA-DNA homology studies: Xanthomonas as a model system. Int. J. Syst. Evol. Microbiol. 50:665-677.

Rademaker, J. L. W., Louws, F. J., Schultz, M. H., Rossbach, U., Vauterin, L., Swings, J., and Bruijn, F. J. 2005. A comprehensive species to isolate taxonomic framework for Xanthomonas. Phytopathology 95:1098-1111.

Richter, M., and Rosselló-Móra, R. 2009. Shifting the genomic gold standard for the prokaryotic species definition. Proc. Natl. Acad. Sci. 106:19126-19131. 
Robbs, C. F., Ribeiro, R. D. L., and Kimura, O. 1974. Sobre a posição taxonômica de Pseudomonas mangiferaeindicae Patel et al. 1948, agente causal da "Mancha bacteriana" das folhas da mangueira (Mangifera indica L.). Arq. Univ. Fed. Rur. Rio de Janeiro 4:11-14.

Rodrigues Neto, J., Detéfano, S. A. L., Rodrigues, L. M. R., Pelloso, D. S., and Oliveira Júnior, L. C. 2011. Grapevine bacterial canker in the state of São Paulo, Brazil: Detection and eradication. Trop. Plant Pathol. 36:42-44.

Ronquist, F., Teslenko, M., van der Mark, P., Ayres, D. L., Darling, A., Höhna, S., Larget, B., Liu, L., Suchard, M. A., and Huelsenbeck, J. P. 2012. Mrbayes 3.2: Efficient Bayesian phylogenetic inference and model choice across a large model space. Syst. Biol. 61:539-542.

Silva, W. J., Jr., Farias, A. R. G., Lima, N. B., Benko-Iseppon, A. M., Aburjaile, F., Balbino, V. Q., Falcão, R. M., Paiva, S. S. L., Jr., Sousa-Paula, L. C., Souza, E. B., Mariano, R. L. R., and Gama, M. A. S. 2018. The genome sequence of Xanthomonas citri pv. anacardii strain IBSBF2579 from Northeast of Brazil. Genome Announc. 6:e01574-e17.

Sowfford, D. L. 2002. Paup*. Phylogenetic analysis using parsimony (*and other methods). Version 4. Sinauer Associates, Sunderland, MA.

Staden, R., Beal, K. F., and Bonfield, J. K. 1998. The Staden package. Pages 115-130 in: Bioinformatics Methods and Protocols. S. Misener and S. A. Krawetz, eds. Humana Press, New York.

Stoyanova, M., Vancheva, T., Moncheva, P., and Bogatzevska, N. 2014. Differentiation of Xanthomonas spp. causing bacterial spot in Bulgaria based on Biolog System. Int. J. Microbiol. 2014:1-7.

Takita, M. A., Borges, K. M., Reis, M. S., and Destéfano, S. A. L. 2006. Analysis of genomic sequences of Xanthomonas campestris pv. viticola gives support to a taxonomic reclassification. In: Reunião Anual da Sociedade Brasileira de Bioquímica e Biologia Molecular, XXXV, Águas de Lindóia. Abstracts. Sociedade Brasileira de Bioquímica e Biologia Molecular, São Paulo.

Takita, M. A., Souza, A., Borges, K. M., Coleta-Filho, H. D., Rodrigues Neto, J., and Machado, M. A. 2004. A região rpf (regulation of pathogenicity factors) distingue espécies de Xanthomonas. Fitopatol. Bras. 29:254.

Tamura, K., Peterson, D., Peterson, N., Stecher, G., and Nei, M. 2011. MEGA5: Molecular evolutionary genetics analysis using maximum likelihood, evolutionary distance, and maximum parsimony methods. Mol. Biol. Evol. 28:2731-2739.

Trindade, L. C., Lima, M. F., and Ferreira, M. A. S. V. 2005. Molecular characterization of Brazilian strains of Xanthomonas campestris pv. viticola by rep-PCR fingerprinting. Fitopatol. Bras. 30:46-54.

Vauterin, L., Hoste, B., Kersters, K., and Swings, J. 1995. Reclassification of Xanthomonas. Int. J. Syst. Bacteriol. 45:472-489.

Verniere, C., Pruvost, O., Civerolo, E. L., Gambin, O., Jacquemoud-Collet, J. P., and Luisetti, J. 1993. Evaluation of the Biolog substrate utilization system to identify and assess metabolic variation among strains of Xanthomonas campestris pv. citri. Appl. Environ. Microbiol. 59:243-249.

Viana, F. M. P., Ferreira, M. A. S. V., Mariano, R. L. R., Saraiva, H. A. O., and Trindade, L. C. 2006. Mancha-de-Xanthomonas: Nova doença do cajueiro. Fortaleza: Empresa Brasileira de Pesquisa Agropecuária (EMBRAPA), Boletim de Pesquisa e Desenvolvimento, 24.

Young, J. M., Dye, D. W., Bradbury, J. F., Panagopoulos, C. G., and Robbs, C. F. 1978. A proposed nomenclature and classification for plant pathogenic bacteria. N.Z. J. Agric. Res. 21:153-177.

Young, J. M., Park, D. C., Shearman, H. M., and Fargier, E. 2008. A multilocus sequence analysis of the genus Xanthomonas. Syst. Appl. Microbiol. $31: 366-377$ 